\title{
Oea
}

JURNAL PENDIDIKAN GEOGRAFI

\section{PENINGKATAN SPATIAL LITERACY PESERTA DIDIK MELALUI PEMANFAATAN MEDIA PETA}

\author{
1Winda Maharani, ${ }^{2}$ Enok Maryani \\ Departemen Pendidikan Geografi, SPs, UPI, email: emaryani@yahoo.com
}

\begin{abstract}
ABSTRAK
Masih kurangnya pemanfaatan media dalam prose pembelajaran yang berhubungan dengan ruang, akibatnya kemampuan spatial literacy peserta didik kurang berkembang. Peserta didik cenderung pasif dan cepat merasa bosan mengikuti pembelajaran. Rendahnya spatial literacy peserta didik dapat menyebabkan mereka kurang cermat dalam hal mengambil keputusan dan memecahkan masalah keruangan dalam kehidupan sehari-hari. Penelitian ini dilakukan berkaitan dengan pemanfaatan media peta dalam pembelajaran IPS di SD Laboratorium Percontohan UPI. Penelitian ini merupakan ekperimen kuasi menggunakan desain nonequivalent groups pre test - post tes pada kelompok eksperimen dan kelompok kontrol. Subjek penelitian adalah peserta didik kelas IV SD Laboratorium Percontohan UPI. Teknik pengumpulan data berupa tes dan angket. Data dianalisis menggunakan uji normalitas dan uji Mann Whitney. Hasil penelitian ini menunjukkan bahwa pemanfaatan media peta dalam pembelajaran IPS dapat meningkatkan spatial literacy peserta didik. Hal ini terlihat dari peningkatan jumlah benar pada setiap indikator spatial literacy yang diberikan. Indikator tersebut adalah menentukan lokasi, mengidentifikasi orientasi keruangan, menentukan jarak terdekat serta mengidentifikasi objek melalui simbol-simbol pada peta. Hasil penelitian ini dapat menjadi saran bagi guru dan pihak sekolah untuk terus memfasilitasi pembelajaran IPS dengan media yang sesuai terutama media peta untuk materi yang terkait dengan ruang, sehingga dapat meningkatkan spatial literacy peserta didik.
\end{abstract}

Kata kunci: media peta, spatial literacy.

\section{PENDAHULUAN}

Pengetahuan yang berhubungan dengan disiplin ilmu-ilmu sosial sangatlah diperlukan baik yang berhubungan dengan ruang lingkup bahasan, objek yang dipelajari, metode maupun pendekatan dari tiap-tiap disiplin ilmu sosial seperti ekonomi, sejarah, sosiologi, antropologi dan geografi. Di Sekolah Dasar, disiplin ilmu-ilmu sosial tersebut terintegrasi pada mata pelajaran Ilmu Pengetahuan Sosial (IPS). Hal ini lebih ditegaskan lagi oleh Saidiharjo (1996: 4) bahwa "IPS merupakan hasil kombinasi atau hasil pemfusian atau perpaduan dari sejumlah mata pelajaran seperti: geografi, ekonomi, sejarah, sosiologi, antropologi, politik." Dalam aspek majemuk ini, aspek geografi memberikan kesempatan kepada siswa untuk dapat mempelajari tentang ruang dan hubungannya dengan kehidupan siswa sebagai masyarakat.

Geografi mempelajari persamaan dan perbedaan fenomena geosfer dengan sudut pandang lingkungan atau kewilayahan dalam konteks keruangan (Sumaatmadja, 2004). Seperti yang telah dijelaskan oleh National Geography bahwa "Geographic skills provide necessary tools and techniques to think spatially. They enable to observe patterns, associations, and spatial order. Geographic representations ... are essential because they assist in visualizing spatial arrangements and patterns" (National Geography Standard, 2012). Geografi mempelajari tentang ruang. Kecerdasan dan keterampilan manusia dalam memanfaatkan ruang, akan memberikan arah bagaimana alam dimodi- 
fikasi untuk kelangsungan hidupnya (Maryani, 2015, hlm. 3).

Pada umumnya kesulitan siswa dalam memahami konsep spasial adalah kurangnya aktifitas siswa pada saat pembelajaran, kurang dilibatkannya siswa dalam membuat produk-produk pembelajaran, serta kurang memanfaatkan media yang dapat mengembangkan kemampuan kognitif dan keterampilan siswa. Siswa akan lebih tertarik jika dalam pembelajaran guru memberikan kesempatan kepada mereka untuk menumbuhkan kreativitas. Sehubungan hal tersebut, maka peran guru dalam upayanya menciptakan pembelajaran yang efektif dan bermakna bagi siswa sangat penting.

Pada penelitian ini, spatial literacy akan menjadi fokus utamanya. Apa kekhususan dari kemelekan ruang (spatial literacy) tersebut bagi anak SD? Sebuah perguruan tinggi terbaik di Amerika Serikat, Carleton College merumuskan bahwa "Spatial literacy is the ability to use the properties of space to communicate, reason, and solve problems," yang berarti bahwa spatial literacy adalah kemampuan untuk menggunakan sifat-sifat ruang dalam berkomunikasi, memberikan alasan serta memecahkan masalah. Pada penelitian ini, untuk mendukung ketercapaian siswa SD dalam hal berpikir spasial/keruangan, pemahaman pengetahuan yang berhubungan dengan keruangan dapat dibantu dengan dengan menggunakan media peta.

Peta adalah gambaran atau representasi unsur-unsur ketampakan abstrak yang dipilih dari permukaan bumi yang ada kaitannya dengan permukaan bumi atau benda-benda angkasa, yang pada umumnya digambarkan pada suatu bidang datar dan diperkecil/diskalakan (International Cartographic Association, 2003). Badan Koordinasi Survei dan Pemetaan Nasional (sekarang menjadi Badan Informasi Geospasial) mendefinisikan peta sebagai wahana penyimpanan dan penyajian data kondisi lingkungan, merupakan sumber informasi bagi para perencana dan pengambilan keputusan pada tahapan dan tingkatan pembangunan (2005). Melihat definisi tentang peta, pembelajaran Geografi akan lebih menarik bagi siswa jika guru menggunakan media peta.

Piaget dalam Budiningsih (2004, hlm. 38-39) mengemukakan bahwa rentang usia anak SD yang berada pada 7 - 11 tahun, yaitu berada pada tahap operasional konkret, yang memiliki ciri bahwa anak sudah mulai menggunakan aturan-aturan yang jelas dan logis, dengan benda-benda yang bersifat konkret. Sehingga dalam pembelajaran guru seharusnya melibatkan siswa dengan sesuatu yang nyata. Dalam hal ini, peta merupakan media atau alat bantu bagi siswa SD yang dapat memperlihatkan gambaran konkret tentang muka bumi yang secara detil, sehingga memudahkan kita dalam mencari letak suatu lokasi. Sobel dalam Maxim (2010, hlm. 214) menjelaskan tentang "pendekatan dunia kecil", yaitu pendekatan yang menyarankan guru kelas untuk lebih mengenalkan peserta didiknya dengan dunia terdekat mereka terlebih dahulu.

Kegiatan pembelajaran yang dibutuhkan adalah yang mampu menghasilkan kemampuan untuk belajar, bukan hanya memperoleh pengetahuan, keterampilan, dan sikap, tetapi yang lebih penting adalah bagaimana pengetahuan, keterampilan, dan sikap itu diperoleh siswa. Kegiatan membaca peta sebenarnya sudah banyak dilakukan oleh guru, namun guru hanya terikat pada perintah dari buku paket. Siswa belum banyak diberikan kesempatan untuk menggali kemampuannya dalam membaca peta. Kegiatan ini bisa dimulai dari lingkungan terdekatnya terlebih dahulu, seperti peta ruang kelas ataupun lingkungan rumahnya.

Pemahaman lingkungan terdekat siswa terutama pemahaman akan aspek keruangan dapat dimaksimalkan dengan bantuan media, salah satunya adalah media peta. Atas dasar permasalahan yang telah dipaparkan, selanjutnya penelitian ini diberi judul "Peningkatan Spatial Literacy 
Siswa Sekolah Dasar Melalui Pemanfaatan Media Peta Dalam Pembelajaran IPS."

Penelitian serupa yang dirujuk dalam menyusun penelitian ini adalah penelitian yang dilakukan di Turki oleh Yusuf Kilinc dengan judul penelitiannya "A Study On The Maps Skills of Primary School Students: A Case of $7^{\text {th }}$ and $8^{\text {th }}$ Grades." Studi kasus yang dilakukan oleh Kilinc ini mengindentifikasi bagaimana siswa SD dalam menggunakan peta? Betapa pentingnya peta dalam membantu banyak hal di kehidupan manusia. Bagi siswa SD, membiasakan diri untuk berpikir spasial dapat membantu mereka dalam menemukan solusi bagi masalah mereka. Kilinc memberikan 29 pertanyaan tentang peta kepada 194 siswa SD dan hasil Studi Kilinc menunjukkan $78,9 \%$ siswa menjawab benar dan $21,1 \%$ menjawab salah.

Mamik Sumarmi dari Universitas Terbuka Surabaya juga telah melakukan penelitian serupa pada tahun 2006. Penelitian Sumarmi berjudul "Peningkatan Pemahaman Peta Melalui Pendekatan Wilayah Dalam Pembelajaran IPS SD." Penelitian tersebut menjabarkan bermacam-macam peta dan pemanfaatannya yang diajarkan pada siswa kelas IV SD dan Sumarmi memanfaatkan peta penyebaran suku, sumber daya alam, dan peninggalan bersejarah para pahlawan sebagai media di dalam pembelajaran IPS. Hasilnya pembelajaran IPS menjadi semakin menarik perhatian siswa dengan peta sebagai media serta dihubungkan dengan hal-hal konkret dalam kehidupan sehari-hari siswa.

Rumusan masalah penelitian dijabarkan dalam pertanyaan-pertanyaan sebagai berikut 1) Apakah dengan memanfaatkan media peta dalam pembelajaran IPS dapat meningkatkan spatial literacy siswa? 2) Bagaimanakah respons siswa terhadap pembelajaran IPS dengan memanfaatkan media peta?

Tujuan penelitian ini adalah untuk: 1) mengidentifikasi peningkatan spatial literacy siswa kelas IV SD Laboratorium Percontohan UPI dalam pembelajaran IPS dengan memanfaatkan media peta; 2) memperoleh gambaran tentang respons siswa dalam pembelajaran IPS dengan memanfaatkan media peta.

\section{METODE PENELITIAN}

Jenis penelitian yang digunakan dalam penelitian ini adalah penelitian kuasi eksperimen. Ali (2011: 284) mengemukakan studi kuasi-eksperimental adalah studi eksperimen, hanya saja dalam pelaksanaannya terdapat kendala pemenuhan kriteria terkait dengan pemilihan subjek sampel secara random dan penugasan subjek secara random karena dalam riset melibatkan manusia, seperti dalam riset prilaku dan sosial.

Subjek dalam penelitian ini adalah siswa kelas IV SD Laboratorium Percontohan UPI dengan siswa kelas IV A sebagai kelas eksperimen dan siswa kelas IV B sebagai kelas kontrol. Instrumen yang digunakan pada penelitian ini berupa tes spatial literacy dan angket respon siswa. Instrumen pertama yang digunakan untuk mengetahui hasil pembelajaran mencakup pre test (tes awal) dan post test (tes akhir), baik dikelas eksperimen maupun kontrol. Sedangkan instrumen kedua adalah angket yang akan diberikan untuk mengetahui respon siswa terhadap pembelajaran IPS dengan memanfaatkan media peta. Data yang terkumpul dianalisis dengan menggunakan bantuan program SPSS versi 20 for Windows. Uji yang digunakan untuk menguji hipotesis dalam penelitian ini adalah uji-t dan uji Mann Whitney.

\section{HASIL DAN PEMBAHASAN}

Hasil dalam penelitian ini adalah berupa hasil deskriptif pre test data kelas eksperimen dan kelas kontrol, hasil deskriptif post test data kelas eksperimen dan kelas kontrol analisis hasil pre test kelas eksperimen dan kelas kontrol, analisis hasil post test kelas eksperimen dan kelas kontrol, uji beda dan uji Mann Whitney untuk menguji hipotesis. Hasil deskriptif pre test kelas eksperimen seperti pada tabel 1 . 
Tabel 1. Deskripsi Hasil Pre Test Kelas Eksperimen

\begin{tabular}{lcc}
\hline \multicolumn{1}{c}{ Descriptives } & \multicolumn{2}{c}{ KELAS EKSPERIMEN } \\
\cline { 2 - 3 } & Statistic & Std. Error \\
\hline Mean & 18.59 & 1.614 \\
\hline Std. Deviation & 7.570 & \\
\hline Minimum & 2.00 & \\
\hline Maximum & 29.00 & \\
\hline
\end{tabular}

Berdasarkan Tabel 1, rata - rata nilai pre test kelas eksperimen 18.59 dari 37 soal, artinya ketercapaian indikator spatial literacy siswa pada kelas eksperimen masih

cukup rendah. Hal ini dapat diketahui dengan melakukan analisis jawaban benar dari setiap nomor soal pada siswa di kelas eksperimen.

Tabel 2. Rangkuman Hasil Analisis Jawaban Siswa Kelas Eksperimen

\begin{tabular}{clc}
\hline No & \multicolumn{1}{c}{ Indikator } & Jumlah Nomor Berskor Rendah \\
\hline 1 & Menentukan lokasi & 4 nomor \\
\hline 2 & Menentukan jarak & 5 nomor \\
\hline 3 & Mengidentifikasi orientasi & 4 nomor \\
\hline 4 & Mengidentifikasi objek melalui simbol & 5 nomor \\
\hline
\end{tabular}

Pada tabel 2 tentang rangkuman hasil analisis jawaban siswa, masing-masing indikator spatial literacy yang dimaksudkan pada penelitian ini masih belum bisa dicapai oleh siswa pada kelas eksperimen dengan rata-rata jumlah nomor antara 4 sampai 5 nomor. Maka dari itu, rangkuman juga dapat digunakan sebagai gambaran guru untuk melakukan pembelajaran IPS dengan memanfaatkan media peta pada kelas eksperimen. Guru diharapkan dapat memanfaatkan media peta dengan sebaikbaiknya dalam pembelajaran IPS, agar siswa dapat lebih memahami tentang cara menemukan lokasi pada peta, menentukan jarak terdekat yang harus ditempuh dalam menuju suatu lokasi, mengidentifikasi secara tepat arah mata angin (orientasi) serta mengidentifikasi secara tepat suatu objek melalui simbol pada peta.

Tabel 3. Deskripsi Hasil Pre Test Kelas Kontrol

\begin{tabular}{lrrr}
\hline \multicolumn{1}{c}{ Descriptives } & \multicolumn{2}{c}{ KELAS KONTROL } & Std. Error \\
\cline { 2 - 4 } & Statistic & & 0.902 \\
\hline Mean & 20.21 & \\
\hline Std. Deviation & 4.771 & \\
\hline Minimum & 8.00 & \\
\hline Maximum & 26.00 & \\
\hline
\end{tabular}

Berdasarkan Tabel 3, rata - rata nilai pre test kelas kontrol adalah 20,21 dari 37 soal yang diberikan. Jika dibandingkan

dengan rata-rata nilai pre test kelas eksperimen, kelas kontrol mempunyai nilai rata-rata pre test yang lebih besar.

Tabel 4. Rangkuman Hasil Analisis Jawaban Siswa Kelas Kontrol

\begin{tabular}{clc}
\hline No & \multicolumn{1}{c}{ Indikator } & Jumlah Nomor Berskor Rendah \\
\hline 1 & Menentukan lokasi & 4 nomor \\
\hline 2 & Menentukan jarak & 5 nomor \\
\hline 3 & Mengidentifikasi orientasi & 3 nomor \\
\hline 4 & Mengidentifikasi objek melalui simbol & 3 nomor \\
\hline
\end{tabular}

Berdasarkan Tabel 4, spatial literacy siswa di kelas kontrol tidak jauh berbeda dengan siswa di kelas eksperimen, hanya saja pencapaian indikator "mengiden- tifikasi orientasi" dan "mengidentifikasi objek melalui simbol" oleh siswa kelas kontrol sedikit lebih tinggi daripada siswa kelas eksperimen. Guru akan tetap 
melakukan pembelajaran pada kelas kontrol, hanya saja pembelajaran dilakukan dengan cara seperti biasa, yaitu membaca buku teks dan menjelaskan kepada siswa, tanpa memanfaatkan media peta.

Sebagai tindak lanjut setelah mengetahui rata-rata nilai dan analisis jawaban berskor rendah pada kedua kelas, maka dilakukan uji normalitas pada kedua kelas. Uji normalitas ini berguna untuk melihat apakah data spatial literacy berupa soal yang diberikan kepada siswa di kedua kelas memiliki sebara distribusi yang normal atau tidak.

Tabel 5. Uji Normalitas Hasil Pre Test Kedua Kelas

\begin{tabular}{llccc}
\hline & Kelas & \multicolumn{3}{c}{ Shapiro-Wilk } \\
\cline { 3 - 5 } & & Statistic & df & Sig. \\
\hline \multirow{2}{*}{ Nilai Pre test } & Eksperimen &, 950 & 22 &, 314 \\
& Kontrol &, 875 & 28 &, 003 \\
\hline
\end{tabular}

Output ini menjelaskan hasil uji Uji normalitas data pre test kelas apakah sebuah distribusi data bisa eksperimen berdistribusi normal sedangdikatakan normal ataukah tidak dengan kan pada kelas kontrol data tidak pedoman pengambilan keputusan sebagai berdistribusi normal. Maka dari itu, tidak berikut:

- Jika Sig. > 0,05, maka data berdistribusi normal;

- Jika Sig. < 0,05, maka data tidak perlu dilakukan uji homogenitas data pre test, sebagai gantinya dilakukanlah uji Mann Whitney untuk mengetahui apakah berdistribusi normal. data berasal dari populasi yang memiliki varians yang sama atau tidak.

Tabel 6. Uji Mann Whitney

\begin{tabular}{llllc}
\hline \multicolumn{1}{c}{ Null Hypothesis } & \multicolumn{1}{c}{ Test } & Sig. & Decision \\
\hline 1 & $\begin{array}{l}\text { The distribution of Nilai Pre } \\
\text { test is the same across } \\
\text { categories of Kelas }\end{array}$ & $\begin{array}{l}\text { Independent-Samples } \\
\text { Mann-Whitney U Test }\end{array}$ & .576 & $\begin{array}{c}\text { Retain the null } \\
\text { hypothesis }\end{array}$ \\
\hline
\end{tabular}

Pada Tabel 6, didapat nilai sig. dari uji Mann Whitney 0.576 dengan pedoman pengambilan keputusan sebagai berikut:

- Jika nilai sig. atau nilai probabilitas $<0,05$, maka data berasal dari populasi yang mempunyai varians tidak sama

- Jika nilai sig. atau nilai probabilitas $>0,05$, maka data berasal dari populasi populasi yang mempunyai varians sama Berarti bahwa data pre test yang telah diketahui hasilnya berasal dari populasi yang mempunyai varians sama atau tidak terdapat perbedaan yang signifikan pada kemampuan awal siswa kedua kelas, kemampuan yang dimaksud adalah spatial literacy. Tahap selanjutnya setelah pre test adalah pemberian perlakuan kemudian memberikan post test. Post test dilakukan untuk mengetahui pengetahuan akhir siswa mengenai spatial literacy setelah dilakukan pembelajaran IPS dengan memanfaatkan media peta pada kelas eksperimen dan tanpa memanfaatkan media peta pada kelas kontrol.

Tabel 7. Deskriptif Hasil Post Test Kelas Eksperimen

\begin{tabular}{lrc}
\hline \multirow{2}{*}{ Descriptives } & \multicolumn{2}{c}{ KELAS EKSPERIMEN } \\
\cline { 2 - 3 } & Statistic & Std. Error \\
\hline Mean & 29.89 & 0.478 \\
\hline Std. Deviation & 2.486 \\
\hline Minimum & 25 \\
\hline Maximum & 35 \\
\hline
\end{tabular}


Rata-rata nilai post test kelas eksperimen adalah 29.89 dari 37 soal. Rata-rata ini meningkat jika dibandingkan dengan rata-rata nilai pre test sebelumnya. Peningkatan tersebut sebanyak 11.3. Tidak lagi terdapat indikator spatial literacy yang memiliki skor rendah pada hasil post test di kelas eksperimen. Hal tersebut membuktikan bahwa setelah melakukan pembelajaran IPS dengan memanfaatkan media peta, spatial literacy siswa kelas eksperimen meningkat. Selanjutnya, perhitungan deskriptif hasil post test pada kelas kontrol dapat dilihat pada tabel 8 .

Tabel 8. Deskriptif Hasil Post Test Kelas Kontrol

\begin{tabular}{|c|c|c|}
\hline \multirow{2}{*}{ Descriptives } & \multicolumn{2}{|c|}{ KELAS KONTROL } \\
\hline & Statistic & Std. Error \\
\hline Mean & 21.32 & 1.036 \\
\hline Std. Deviation & 5.484 & \\
\hline Minimum & 4 & \\
\hline Maximum & 28 & \\
\hline
\end{tabular}

Rata-rata nilai post test kelas kontrol adalah 21.32 dari 37 soal. Rata-rata nilai post test pada kelas kontrol ini mengalami peningkatan tetapi tidak signifikan yaitu hanya sebesar 1.11. Indikator spatial literacy "mengidentifikasi orientasi" dan "menentukan jarak" masih memperoleh skor rendah. Tahapan berikutnya adalah uji normalitas data post test, didapatkan hasil seperti yang tertera pada tabel 9 .

Tabel 9. Uji Normalitas Hasil Post Test

\begin{tabular}{llrrr}
\hline & \multirow{2}{*}{ Kelas } & \multicolumn{3}{c}{ Shapiro-Wilk } \\
\cline { 2 - 5 } & Eksperimen & Statistic & df & \multicolumn{2}{c}{ Sig. } \\
\hline \multirow{2}{*}{ Nilai Post test } & Kontrol &, 952 & 27 &, 235 \\
& &, 797 & 28 &, 000 \\
\hline
\end{tabular}

Tabel 9 menjelaskan hasil uji data post test, apakah distribusi data post test tentang spatial literacy pada penelitian ini bisa dikatakan normal atau tidak, dengan pedoman pengambilan keputusan berikut: - Jika Sig. > 0,05, data berdistribusi normal; - Jika Sig. < 0,05, data tidak berdistribusi normal.
Disimpulkan, uji normalitas data post test kelas eksperimen berdistribusi normal dan kelas kontrol tidak berdistribusi normal. Karena itu, tidak perlu dilakukan uji homogenitas data post test tetapi dilakukan uji Mann Whitney untuk mengetahui apakah data berasal dari populasi yang memiliki varians yang sama atau tidak.

Tabel 10. Uji Mann Whitney

\begin{tabular}{llllc}
\hline \multicolumn{1}{c}{ Null Hypothesis } & Test & Sig. & Decision \\
\hline 1 & $\begin{array}{l}\text { The distribution of Nilai Pre } \\
\text { test is the same across } \\
\text { categories of Kelas }\end{array}$ & $\begin{array}{l}\text { Independent-Samples } \\
\text { Mann-Whitney U Test }\end{array}$ & .000 & $\begin{array}{c}\text { Reject the null } \\
\text { hypothesis }\end{array}$ \\
\hline
\end{tabular}

Terlihat pada tabel tersebut bahwa didapatkan nilai sig. dari uji Mann Whitney adalah 0.000 dengan pedoman pengambilan keputusan sebagai berikut:

- Jika nilai sig. atau nilai probabilitas < 0,05, data berasal dari populasi - populasi yang mempunyai varians tidak sama;

- Jika nilai sig. atau nilai probabilitas $>0,05$, data berasal dari populasi - populasi yang mempunyai varians sama.
Disimpulkan bahwa "data berasal dari populasi yang mempunyai varians tidak sama" atau "spatial literacy siswa pada kelas yang melakukan pembelajaran IPS dengan memanfaatkan media peta (kelas eksperimen) lebih baik daripada kelas yang tanpa memanfaatkan media peta (kelas kontrol)." Dengan demikian, pemanfaatan media peta dalam pembelajaran IPS dapat meningkatkan spatial literacy siswa. 
Tabel 11. Hasil Angket Respon Siswa

\begin{tabular}{|c|c|c|c|c|c|c|}
\hline \multirow{2}{*}{ No } & \multirow{2}{*}{ Pernyataan } & \multicolumn{5}{|c|}{ Respon } \\
\hline & & SL & $S$ & KD & $\mathrm{P}$ & TP \\
\hline 1. & $\begin{array}{l}\text { Pembelajaran IPS dengan memanfaatkan media peta } \\
\text { menyenangkan }\end{array}$ & $52 \%$ & $48 \%$ & 0 & 0 & 0 \\
\hline 2. & $\begin{array}{l}\text { Belajar IPS dengan memanfaatkan media peta } \\
\text { membuat saya lebih aktif }\end{array}$ & $44 \%$ & $56 \%$ & 0 & 0 & 0 \\
\hline 3. & $\begin{array}{l}\text { Saya menjadi lebih mengerti akan simbol-simbol } \\
\text { pada peta }\end{array}$ & $56 \%$ & $44 \%$ & 0 & 0 & 0 \\
\hline 4. & $\begin{array}{l}\text { Saya dapat dengan mudah menentukan jarak dengan } \\
\text { menggunakan peta }\end{array}$ & $67 \%$ & $30 \%$ & $3 \%$ & 0 & 0 \\
\hline 5. & $\begin{array}{l}\text { Saya dapat dengan mudah mengetahui batas-batas } \\
\text { lokasi dengan bantuan arah mata angin }\end{array}$ & $44 \%$ & $56 \%$ & 0 & 0 & 0 \\
\hline 6. & $\begin{array}{l}\text { Saya dapat menentukan arah mata angin dengan } \\
\text { tepat }\end{array}$ & $63 \%$ & $37 \%$ & 0 & 0 & 0 \\
\hline 7. & $\begin{array}{l}\text { Saya dapat menemukan lokasi lebih cepat dengan } \\
\text { bantuan peta }\end{array}$ & $59 \%$ & $41 \%$ & 0 & 0 & 0 \\
\hline 8. & $\begin{array}{l}\text { Saya merasa masih ada beberapa kesulitan dalam } \\
\text { mengerjakan latihan/tes }\end{array}$ & 0 & 0 & 0 & $41 \%$ & $59 \%$ \\
\hline 9. & $\begin{array}{l}\text { Saya merasa tertarik untuk terus menggunakan peta } \\
\text { dalam kehidupan sehari-hari }\end{array}$ & $41 \%$ & $56 \%$ & 0 & $3 \%$ & 0 \\
\hline 10. & $\begin{array}{l}\text { Saya memperhatikan peta-peta yang ditampilkan } \\
\text { oleh guru }\end{array}$ & $67 \%$ & $33 \%$ & 0 & 0 & 0 \\
\hline
\end{tabular}

Secara keseluruhan dapat diinterpretasikan bahwa pada setiap pernyataan yang ada pada angket siswa memberikan respon yang baik bahkan sangat baik.

\section{Pemanfaatan Media Peta dapat Mening- katkan Spatial Literacy Siswa}

Data pre test dan post test yang telah terkumpul, dianalisis dengan pengujian yang telah ditetapkan dan menunjukkan bahwa spatial literacy meningkat lebih tinggi pada kelas yang melakukan pembelajaran IPS dengan memanfaatkan media peta. Ini berati bahwa peta berhasil melakukan tugasnya dengan baik sebagai media pembelajaran. Sebagaimana diungkapkan oleh Gerlach \& Ely dalam Arsyad (2013, hlm. 3) bahwa media apabila dipahami secara garis besar adalah manusia, materi, atau kejadian yang membangun kondisi yang membuat siswa mampu memperoleh pengetahuan, keterampilan, atau sikap. Melalui peta siswa dapat mengetahui kondisi dari masa lalu sampai masa sekarang, sehingga dapat memprediksi kondisi yang akan datang. Hal tersebut akan berpengaruh pada meningkatnya kecerdasan siswa dalam hal memecahkan masalah dan mengambil keputusan dalam kehidupan sehari-hari, sepert yang telah dijelaskan sebelumnya bahwa spatial literacy juga merangkum kedua kemampuan tersebut.

Abdurrachman (1985, hlm. 12-13) dalam disertasinya menjabarkan manfaat yang dapat diperoleh siswa setelah membaca peta, yaitu: 1) peta mempermudah identifikasi tentang letak, lokasi, distribusi dan orientasi keruangan. Unsurunsur tersebut berhubungan dengan arah, jarak dan bentuk; 2) peta dapat mempermudah dan memperjelas pemahaman konsep-konsep yang berhubungan dengan arah, jarak, letak, luas dan bentuk, andaikata digunakan secara tepat pada waktu proses belajar-mengajar berlangsung; 3) peta merupakan alat untuk mengekspresikan gagasan-gagasan, antara lain persepsi seseorang tentang lingkungan berupa konstruk keruangan; 4) peta dapat memperbaiki, mengubah dan memperkaya konstruk keruangan seseorang tentang lingkungan.

Melihat manfaat membaca peta tersebut, maka peta merupakan media yang dapat meningkatkan spatial literacy siswa. Education for All Global Monitoring Report dalam Maryani (2015, hlm. 8) 
mengungkapkan bahwa istilah literasi mengandung pengertian: 1) literacy as an autonomous set of skills; 2) literacy as applied, practised and situated;3) literacy as a learning process; 4) literacy as text.

Dari pengertian tersebut dapat diketahui bahwa di dalam literasi pembelajaran akan membentuk satu kesatuan keterampilan, penerapan dan kefasihan dalam situasi tertentu, serta proses pembelajaran yang penuh makna. Begitu juga dengan pembelajaran IPS dengan memanfaatkan media peta, siswa akan terlatih untuk berpikir secara spasial. National Research Council (2006) juga memaparkan bahwa dengan berpikir spasial, kita akan mendapatkan tiga hal, yaitu spatial concept, spatial representations dan juga spatial reasoning. Ketiga hal tersebutlah yang akan mengarahkan kita untuk berikir lebih terarah, melihat ruang dari sudut pandang 3 dimensi, serta membantu kita untuk mengambil keputusan.

Selain itu, Kerski dalam Zwartjes (2008) mengemukakan bahwa "summarizes spatial thinking as the ability to study the characteristics and the interconnected processes of nature and human impact in time and at appropriate scale. In fact this is real geography: be able to think critically about the earth, the activities of people and the interaction between the two. Thinking spatially is more than knowing where things are located, it's about asking geographic questions: why there, how originated and what if...".

Bahwa dengan berpikir spasial siswa akan terlatih untuk menjawab pertanyaanpertanyaan geografis seperti mengapa di sana, bagaimana cara kerjanya atau bagaimana jika dan lain-lain. Berdasarkan pada teori di atas, maka pemanfaatan media peta dalam pembelajaran IPS di kelas IV dinilai sebagai perlakuan yang tepat untuk membantu siswa dalam meningkatkan taraf berpikir mereka untuk menemukan solusi dari masalah keruangan yang terdapat di sekitar mereka. Dapat disimpulkan bahwa media peta dapat memberikan dampak baik berupa pening- katan spatial literacy siswa kelas IV SD Laboratorium Percontohan UPI.

\section{Respon Siswa terhadap Pembelajaran IPS dengan Memafaatkan Media Peta}

Siswa kelas IV A sebagai kelas yang mendapatkan perlakuan berupa pembelajaran IPS dengan memanfaatkan media peta, memberikan respon positif pada hampir semua pernyataan yang diajukan. Menurut mereka, pembelajaran IPS dengan memamnfaatkan media peta membuat suasana belajar mereka menjadi lebih menyenangkan, mereka menjadi lebih aktif, lebih paham akan penjelasan guru, serta membatu mereka dalam menjawab pertanyaan yang berkaitan dengan spatial literacy. Susanto (2012, hlm. 85) menyatakan bahwa bagi siswa, belajar merupakan proses interaksi antara berbagai potensi diri siswa (fisik, nonfisik, emosi dan intelektual), interaksi siswa dengan guru, siswa dengan siswa lainnya serta lingkungan dengan konsep dan fakta, interkasi dari berbagai stimulus dengan berbagai respons terarah untuk melahirkan perubahan.

Maxim (2010, hlm. 221) yang menilai bahwa peta dapat memiliki cerita tersendiri untuk setiap anak, apabila anak diperkenalkan terlebih dahulu dengan peta lingkungan terdekatnya maka anak akan menggali kemampuan mereka dalam membaca peta, anak dapat menjelaskan secara lebih rinci dengan bantuan peta. Dalam hal ini, guru dituntut untuk memaksimalkan potensi diri dan juga siswa dalam pembelajaran melalui media sebagai stimulus kemampuan siswa, dan dalam hal peningkatan spatial literacy siswa peta adalah media pilihan yang tepat.

\section{SIMPULAN}

Simpulan dalam penelitian ini adalah: 1) Pembelajaran IPS dengan memanfaatkan media peta dapat meningkatkan spatial literacy siswa kelas IV SD Laboratorium Percontohan UPI; 2) Siswa memberikan respon positif setelah melakukan pembel- 
ajaran IPS dengan memanfaatkan media peta.

Saran yang dapat diberikan setelah dilakukannya penelitian ini adalah: 1) Diharapkan bagi para peneliti selanjutnya dapat melakukan penelitian dengan objek penelitian yang belum pernah diteliti sebelumnya yang berkaitan dengan masalah ruang dilihat dari sudut pandang pembelajaran yang dilakukan siswa usia sekolah dasar; 2) Bagi para pembaca pada umumnya, diharapkan penelitian ini dapat menambah referensi yang berkaitan dengan ruang khususnya pada aspek spatial literacy siswa usia sekolah dasar.

\section{DAFTAR PUSTAKA}

Abdurrachman, M. (1985). Hubungan Antara Penggunaan Peta Geografis dengan Image Keruangan dan Pemahaman Siswa Tentang Konsep-Konsep yang Berkaitan dengan arah, Jarak, Letak, Luas dan Bentuk. Bandung: Universitas Pendidikan Indonesia.

Ali, M. (2011). Memahami Riset Prilaku dan Sosial. Bandung: Pustaka Cendekia.

Arsyad, A. 2013. Media Pembelajaran. Jakarta: PT. RajaGrafindo Persada.

BAKOSURTANAL. (2005). Badan Koordinasi Survey dan Pemetaan Nasional. Jakarta.

Budiningsih, A. (2004). Belajar dan Pembelajaran. Penerbit Rinika Cipta, Yogyakarta.

ICA. (2003). International Cartographic Association. Swedia.

Kilinc, Y. (2011). A Study On The Maps Skills Of Primary School Students: A Case Of $7^{\text {th }}$ And $8^{\text {th }}$ Grades. Ohio. Ozean
Publication. European Journal of Education Studies Vol. 3 No. 2.

Maryani, E. (2010). Dimensi Geografi Dalam Kepariwisataan dan Relevansinya Dengan Dunia Pendidikan. Bandung: UPI.

Maryani, E. (2015). Kecerdasan Ruang Dalam Pembelajaran Geografi. Bandung: UPI.

Maxim, George W. 2010. Dynamic Social Studies for Constructivist Classroom: Inspiring Tomorrow's Social Scientists (Ninth Edition). Boston: Allyn \& Bacon, Pearson.

National Geographic Standards. (2012). How to Analyze The Spatial Organization of People, Places, and Environments on Earth's Surface. [online]. Tersedia di http://education.nationalgeographic.com /education/standards/national-geographystandards/?ar_a=1. (4 November 2014).

NRC (National Research Council). (2006). Learning to Think Spatially. Washington D. C. The National Academies Press.

Saidihardjo \& Sumadi HS. (1996). Konsep dasar Ilmu pengetahuan Sosial. (Buku 1). Yogyakarta : FIP IKIP.

Sumaatmadja, N, dkk., (2004). Konsep Dasar IPS. Jakarta: Universitas Terbuka.

Sumarmi, M. (2006). Peningkatan Pemahaman Peta Melalui Pendekatan Wilayah Dalam Pembelajaran IPS SD. Surabaya: UPBJJ. Jurnal Penelitian Didaktika Vol. 1 No. 1 Maret 2006: 75-92.

Zwartjes, L. (2008). iGuess: Introducing GIS Use in Education in Several Subjects. [online]. Tersedia di http://www.herodot.net/conferences/ ayvalik/papers/geotech03.pdf.

(4) November 2014.

